\title{
PENGARUH PENAMBAHAN EKSTRAK SARANG SEMUT (MYRMECODIA SP)TERHADAP PERSENTASE KARKAS DAN PANJANG USUS AYAM BROILER FASE FINISHER
}

\section{The Effect of Addition Ant Nest Exstract (Myrmecodiasp) TowardThe Percentage of Carcassand Long Intestine Broiler Phase Finisher}

\author{
Ertika Fitri Lisnanti ${ }^{1)}$, Nur Fitriyah ${ }^{2)}$, Muhammad Rifqi Muzamil Anwar ${ }^{1)}$ \\ 1) Mahasiswa Program Studi Peternakan, Fakultas Pertanian Universitas Islam Kadiri, Kediri, Indonesia \\ ${ }^{2)}$ Mahasiswa Program Studi Agroteknologi, Fakultas Pertanian Universitas Islam Kadiri, Kediri, Indonesia \\ Email : lisnantiertika@gmail.com
}

\begin{abstract}
ABSTRAK
Penelitian ini bertujuan untuk mengetahui pengaruh penambahan ekstrak sarang semut (Myrmecodia sp) terhadap persentase karkas dan panjang usus ayam broiler fase finisher. Materi yang digunakan dalam penelitian ini menggunakan 80 ayam broiler strain Cobb umur 21 hari. Pakan yang digunakan pakan lengkap (complete feed). Metode dalam penelitian ini adalah percobaan eksperimen. Rancangan yang digunakan dalam penelitian ini menggunakan Rancangan Acak Lengkap (RAL). Perlakuan terdiri atas P0 (Kontrol), P1 $(5 \mathrm{mg} / \mathrm{kg} \mathrm{bb}), P 2(10 \mathrm{mg} / \mathrm{kg} \mathrm{bb}), P 3(15 \mathrm{mg} / \mathrm{kg} \mathrm{bb})$. Variabel yang diukur meliputi persentase karkas dan panjang usus ayam broiler fase finisher. Hasil analisa ragam menunjukkan bahwa penambahan ekstrak sarang semut (Myrmecodia sp) tidak berpengaruh nyata $(P>0,05)$ terhadap persentase karkas dan panjang usus ayam broiler,tetapi pada pemberian Pl (5 mg/kg bb) menunjukkan sedikitkenaikanterhadap persentase karkas. Kesimpulan pada penelitian ini adalah tidak terdapat pengaruh yang nyata penambahan ekstrak sarang semut (Myrmecodia sp) terhadap persentase karkas dan panjang usus ayam broiler fase finisher.
\end{abstract}

Kata kunci: Ayam broiler, ekstrak sarang semut, karkas, panjang usus

How to Cite :

Lisnanti, E. F., Fitriyah, N., \& Anwar, M. R. M. (2018). Pengaruh Penambahan Ekstrak Sarang Semut (Myrmecodia Sp) Terhadap Persentase Karkas dan Panjang Usus Ayam Broiler Fase Finisher. Jurnal Nutrisi Ternak Tropis, 1 (1) 60-68
*Corresponding author:

Ertika Fitri Lisnanti

Email : lisnantiertika@gmail.com

Faculty of Animal Science, Brawijaya University, Veteran Street, Malang, East Java, Indonesia. 65145 


\section{ABSTRACT}

This study aims to know the effect of the addition ant nest extract (Myrmecodia sp) toward the percentage of carcass and long intestine broiler phase finisher. The material in this study was using 80 chickens broiler strain cobb age 21 days. The feed used in this research was complete feed. The method in this study was experiment. The design used in this study was a complete randomized design (RAL). The treatment consists of PO (control), PI (5 $\mathrm{mg} / \mathrm{kg} \mathrm{bb}), P 2(10 \mathrm{mg} / \mathrm{kg} \mathrm{bb}), P 3(15 \mathrm{mg} / \mathrm{kg} \mathrm{bb})$. The variable was measured include percentage of carcass and long intestine broiler phase finisher. The result of variance analysis sowed that the addition of ant nest extract (Myrmecodia sp) had no significant effect $(P>0,05)$ toward the percentage of carcass and long intestine broilers. The conclusion in this study is there is no real effect of addition ant nest extract (Myrmecodia sp) toward the percentage of carcass and long intestine broiler phase finisher.

Keyword: Chicken broiler, ant nest extract, carcass, long intestine

\section{PENDAHULUAN}

Ayam broiler merupakan ayam yang dipelihara untuk menghasilkan daging, penggunaan pakan lebih efisien dan tumbuh lebih cepat sehingga dapat dijual dengan waktu singkat (Scanes et al., 2004). Produksi karkas dan organ dalam salah satunya usus ayam broiler tidak terlepas dari penggunaan antibiotik sebagai pemacu pertumbuhan. Penggunaan antibiotik dapat meningkatkan penyakit infeksi yang resisten terhadap antibiotik pada manusia (Saleha et al., 2009). Bakteri seperti E. Coli dan Salmonella yang mencemari karkas dapat mengakibatkan infeksi pada manusia yang mengonsumsinya dan jika bakteri tersebut resisten terhadap antibiotik maka akan mengakibatkan penyakit serius pada manusia karena kegagalan pengobatan dengan antibiotik. Penggunaan antibiotik dinilai kurang baik dan membahayakan bagi konsumen serta menimbulkan residu. Van den Bogaard et al. (2002) mengemukakan bahwa penggunaan antibiotik secara berlebihan dikhawatirkan akan menyebabkan resistensi mikroorganisme terhadap antibiotik serta akan mengganggu keseimbangan mikroorganisme dalam saluran pencernaan, oleh karena itu ada usaha untuk mencari alternatif pengganti antibiotik dengan menggunakan zat aktif yang ada didalam tanaman (bioaktif).
Tanaman yang mengandung bioaktif salah satunya yaitu sarang semut yang bernama ilmiah (Myrmecodia sp) merupakan tanaman epifit dari suku rubiaceae yang menempel di pohon-pohon besar, yang batang bagian bawahnya menggelembung berisi rongga-rongga (Umbi) yang dihuni jenis semut tertentu (Simanjuntak dan Subroto, 2010). Umbi yang berongga dari batang tersebut biasanya dimanfaatkan sebagai obat dengan cara diolah terlebih dahulu.

Penelitian tentang penambahan ekstrak sarang semut (Myrmecodia sp) terhadap persentase karkas dan panjang usus ayam broiler fase finisher sejauh ini belum diketahui, sehingga perlu dilakukan penelitian. Kandungan senyawa didalam tanaman sarang semut (Myrmecodia sp) selain sebagai obat diduga mempunyai pengaruh lain yaitu terhadap produksi karkas dan organ dalam khususnya panjang usus ayam broiler. Penelitian ini sangat penting dilakukan untuk meningkatkan produksi karkas ayam broiler.

\section{MATERI DAN METODE}

Penelitian ini dilaksanakan di laboratorium lapang jurusan Peternakan Fakultas Pertanian Universitas Islam Kadiri (UNISKA) Kediri dan Laboratorium Kimia Universitas Muhammadiyah Malang. Penelitian ini dilaksanakan pada tanggal 24 
Oktober - 7 Desember 2017 dengan tahapan 24 - 30 Oktober persiapan ekstrak sarang semut, 31 Oktober - 9 November persiapan kandang, $10-29$ November pemeliharaan ayam tanpa percobaan, 30 November - 6 Desember pemeliharaan ayam dengan percobaan dan 7 Desember pemotongan ayam untuk pengambilan data.

Metode penelitian yang digunakan dalam penelitian ini adalah eksperimen yaitu suatu percobaan untuk mengetahui pengaruhnya terhadap subjek percobaan dengan cara memberikan perlakuan tertentu pada beberapa kelompok percobaan dan menyediakan control untuk perbandingan (Lisnanti dan Fitriyah, 2017)

Pemberian ekstrak sarang semut dilakukan setelah ayamberumur 21 hari sampai umur 28 hari. Rancangan yang digunakan adalah Rancangan Acak Lengkap (RAL). Penelitian ini dilaksanakan kurun waktu 7 hari dilakukan 4 perlakuan yang masing- masing perlakuan diulang sebanyak 5 ulangan dengan menggunakan percobaan 4 ekor ayam dalam 1 petak sehingga menghasilkan 20 petak kandang yang akan diterapkan sebagaiberikut:

P0: digunakan sebaga pembanding dari masing-masing perlakuan (kontrol)

P1 : perlakuan dengan penambahan ekstraksarang semut $5 \mathrm{mg} / \mathrm{kg}$ bb

$\mathrm{P} 2$ : perlakuan dengan pemberian ekstrak sarang semut $10 \mathrm{mg} / \mathrm{kg}$ bb

P3 : perlakuan dengan penambahan ekstrak sarang emut $15 \mathrm{mg} / \mathrm{kg}$ bb

Pembuatan Ekstrak SarangSemut

Penelitian ini menggunakan umbi dari sarang semut, dikupas dan diiris tipistipis kemudian dikeringkan. Setelah kering selanjutnya irisan-irisan tersebut diblender agar menjadi serbuk. Untuk memisahkan serbuk antara kasar dan halus dilakukan proses pengayakan, serbuk yang masih kasar dapat digiling kembali. Serbuk yang lolos pengayakan dapa tdigunakan untuk proses selanjutnya yaitu proses ekstraksi (Subroto danSaputro, 2008)
Ernawati dkk. (2015) menyatakan bahwa ekstraksi dilakukan dengan perbandingan sebanyak 100 gram serbuk sarang semut dilarutkan dengan etanol sebanyak 8 liter, etanol tersebut mempunyai kadar $96 \%$ selanjutnya pengadukan dengan menggunakan magnetic stirrer dengan rentan waktuselama 2 jam kemudian di diamkan 24 jam.

Filtrat etanol yang diperoleh disaring dengan corong Buchner, ampas selanjutnya diremaserasi sebanyak 2 kali dengan perlakuan yang sama pada saat proses maserasi. Setelah itu, filtrat yang diperoleh digabung dan dipekatkan dengan rotary evaporator hingga didapatkan ekstrak kental etanol (Ernawati dkk., 2015).

VariabelyangDiamati

a. Persentase karkas, diperoleh dari perbandingan bobot karkas ayam setelah dipotong dengan bobot hidup ayam dikalikan $100 \%$.

Persentase Karkas $==$ $\frac{\text { Bobot Karkas (g) }}{\text { BB Hidup Ayam (g) }} \times 100 \%$

b. Panjang usus, diperoleh dengan mengukur panjang usus mulai dari pangkal usus sampai kloaka.

PelaksanaanPenelitiandiKandang

a. Hari ke-1, DOC yang baru tiba dihitung dan ditimbang satu per satu sambil dicata tkemudian dimasukkan kekandang brooder. DOC diberi air minum yang telahdicampur vitamin dengandosis 1 gram / 2 liter. Pakan diberikan secara ad libitum dengan cara disebar sedikit demi sedikit di alas kandang kandang.

b. Hari ke-2 dan seterusnya pakan disediakan di dalam tempat pakan dengan jumlah sesuai standar kebutuhan ayam.

c. Hari ke-21 pemberian ekstrak sarang semut mulai dilakukan sesuai dosis dan waktu pada perlakuan, sebelum perlakuan ayam dipuasakan 2 jam 
agar ekstrak yang diberikan dapat terkonsumsi secara maximal dan sesudah itu diganti dengan air biasa secara ad libitum.

d. Hari ke-28 ayam dipanen, sebelum disembelih ayam ditimbang terlebih dahulu untuk mengetahui bobot hidup untuk menentukan dalam perhitungan persentase karkas.

Prosedur Koleksi Data

a. Prosedur persentase karkas yaitu ayam percoban yang telah berumur 28 hari kemudian dipotong, sebelum pemotongan tersebut ayam dipuasakan selama 6 jam dan selanjutnya ditimbang terlebih dahulu untuk mengetahui bobot hidup ayam tersebut (Sibarani et al., 2014). Pemotongan ayam dilakukan pada posisi tergantung terbalik selanjutnya leher disayat tapi tidak sampai leher putus (hanya uratnya saja), prinsipnya agar darah keluar keseluruhan atau sekitar 2/3 leher dipotong dan ditunggu 1-2 menit, hal ini agar kualitas daging bagus, tidak mudah tercemar dan tidak mudah rusak. Ayam yang telah dipotong dicelupkan dalam air panas dengan suhu sekitar $60^{\circ} \mathrm{C}$, lama pencelupan ayam sekitar 30 detik. Kemudian dibersihkan dari semuat bulu, dihilangkan bagian kepala sampai pangkal leher, semua isi rongga perut termasuk lemak yang menempel pada dinding rongga perut, kaki sampai ujung paha bagian bawah, kemudian ditimbang (Mubarok dan Sri, 2016).

b. Prosedur data panjang usus yaitu ayam dibedah kemudian diambil organ ususnya dan dibersihkan kotoran yang ada di dalam usus setelah itu dilakukan pengukuran menggunakan pita ukur mulai dari pangkal usus sampai kloaka.
Analisa Data
Penelitian ini menggunakan metode rancangan acak lengkap (RAL). Hasil data penelitian selanjutnya dianalisa secara statistic dengan menggunakan analisa ragam untuk Rancangan Acak Lengkap, dan jika terdapat perbedaan pengaruh yang nyata atau sangat nyata maka akan dilanjutkan dengan uji Beda Nyata Terkecil ( BNT ).

\section{HASIL DAN PEMBAHASAN}

Pengaruh terhadap persentase karkas

Tabel 1. Persentase Karkas Ayam Broiler Fase Finisher.

\begin{tabular}{cccccccc}
\hline \multirow{2}{*}{ Perlakuan } & \multicolumn{5}{c}{ Ulangan } & Rata-rata & Notasi \\
\cline { 2 - 5 } & 1 & 2 & 3 & 4 & 5 & & \\
\hline P0 & 66,21 & 53,71 & 66,90 & 67,18 & 61,80 & 63,16 & ns \\
P1 & 67,68 & 69,01 & 65,32 & 65,14 & 65,09 & 66,45 & ns \\
P2 & 65,94 & 67,39 & 66,17 & 65,79 & 63,30 & 65,72 & ns \\
P3 & 60,56 & 66,26 & 63,80 & 63,25 & 62,46 & 63,26 & ns \\
\hline
\end{tabular}

Keterangan: Notasi ns (non significant) menunjukkan pengaruh tidak nyata $(\mathrm{P}>0,05)$

Hasil penelitian menggunakan penambahan ekstrak sarang semut (Myrmecodia $s p$ ) terhadap persentase karkas dapat dilihat pada Tabel 1. Berdasarkan hasil analisis sidik ragam penelitian tentang penambahan ekstrak sarang semut (Myrmecodia $s p$ ) melalui media air minum tidak memberikan pengaruh nyata $(\mathrm{P}>0,05)$ terhadap persentase karkas. Pada tabel 1 tersebut menunjukkan bahwa hasil perlakuan mempunyai persentase karkas lebih tinggi dibanding kontrol (P0). Kontrol menunjukkan hasil paling rendah 
kemungkinan besar disebabkan perlakuan ini tanpa memberikan ekstrak sarang semut (Myrmecodia $s p$ ). Hasil rataan persentase karkas tertinggi terdapat pada perlakuan 1 (P1) $(5 \mathrm{mg} / \mathrm{kg} \mathrm{bb})$ disusul pada perlakuan 2 (P2) $(10 \mathrm{mg} / \mathrm{kg} \mathrm{bb})$ dan perlakuan 3 (P3) (15 mg/kg bb).

Persentase karkas tertinggi terdapat pada perlakuan 1 (P1) (5 $\mathrm{mg} / \mathrm{kg} \quad \mathrm{bb})$ disebabkan oleh pemberian dosis yang paling sidikit pada perlakuan dan hasil karkas terendah terdapat pada perlakuan 3 (P3) $(15 \mathrm{mg} / \mathrm{kg} \mathrm{bb})$, hal ini juga disebabkan pemberian dosis yang terlalu banyak diantara perlakuan. Pemberian ekstrak sarang semut (Myrmecocodia sp) pada perlakuan 3 (P3) terbukti menurunkan persentase karkas disebabkan terlalu banyak memberikan dosis sehingga membuat lidah ayam menjadi sepat dan menurunkan konsumsi ransum. Hal ini sesuai dengan pendapat Amrullah (2004) yang berpendapat bahwa lidah unggas memiliki sistem perasa berupa gustative or taste buds untuk mengenali rasa makanan dan minuman, sementara indra penciumanya (olfactory system) kurang berkembang. . Konsumsi ransum menurun menyebabkan bobot hidup ayam juga menurun. Hal ini sesuai dengan pendapat Soeparno (2005) yang mengemukakan bahwa salah satu faktor memengaruhi bobot hidup ayam yaitu konsumsi ransum. Rendahnya bobot hidup dibanding standar yang ada disebabkan konsumsi pakan pada ayam broiler rendah. Ayam akan berhenti makan jika kebutuhan energinya sudah tercukupi walaupun kebutuhan nutrisinya belum terpenuhi. Hal ini sesuai dengan pendapat Suprijatna et al. (2005) yang menyatakan bahwa jika ayam kebutuhan energinya telah terpenuhi maka akan mengurangi, bahkan menghentikan konsumsi, tetapi bahan pembentuk jaringan tubuh dan produk kurang maka laju pertumbuhan dan produksinya terganggu untuk itu tingkat dan kandungan pada zat makanan dalam pakan perlu disesuaikan dengan tingkat kandungan energi pakan. Hal ini diperkuat dengan pendapat
Singarimbun et al. (2013) yang mengemukakan bahwa jika kebutuhan energi sudah terpenuhi maka ayam akan berhenti makan.

Tabel 1 yaitu persentase karkas ayam broiler pada hasil penelitian antara $63,16 \%$ $66,45 \%$ dari bobot hidup. Persentase karkas pada penelitian ini hampir mendekati dengan penelitian Dewi (2007) yang memberikan ransum komersial mendapatkan 63,79\%-67,78\% dari bobot hidup, tetapi lebih tingi dari hasil penelitian Syukron (2006) yang memberikan ransum finisher dengan tambahan kepala udang mendapatkan hasil berkisar antara 56,64\%$60,02 \%$ dari bobot hidup. Persentase karkas pada penelitian ini masih lebih rendah dari hasil penelitian Nuraini (2010) yang melaporkan bahwa persentase karkas ayam broiler umur 35 hari berkisar antara $68,02 \%-71,03 \%$ dari bobot hidup. Perbedaan tersebut dapat disebabkan oleh umur ayam broiler pada penelitian ini hanya mencapai umur 28 hari sedangkan pada penelitian Nuraini (2010) mencapai umur 35 hari. Hal ini sesuai dengan pendapat Soeparno (2005) yang menyatakan bahwa salah satu faktor yang memengaruhi bobot hidup ayam broiler adalah lama pemeliharaan.

Persentase karkas selain disebabkan oleh bobot hidup ayam itu sendiri juga dipengaruhi pula oleh penanganan dalam proses pemotongan, pada proses tersebut ayam harus sehat, tidak dalam keadaan lelah, tidak produktif atau bukan bibit. Ayam diistirahatkan selama $12-24$ jam dimaksudkan agar ayam tidak stres, darah dapat keluar sebanyak mungkin saat dipotong, dan cukup energi sehingga proses rigormortis berlangsung secara sempurna (Abubakar, 2003). Hal tersebut dilakukan pada waktu penelitian ini untuk menjaga kualitas karkas, karena menurut Mubarok dan Sri (2016) penanganan dalam proses pemotongan ayam dapat memengaruhi kualitas karkas yang dihasilkan. Grafik persentase karkas untuk lebih jelasnya kami tampilkan pada Gambar 1 


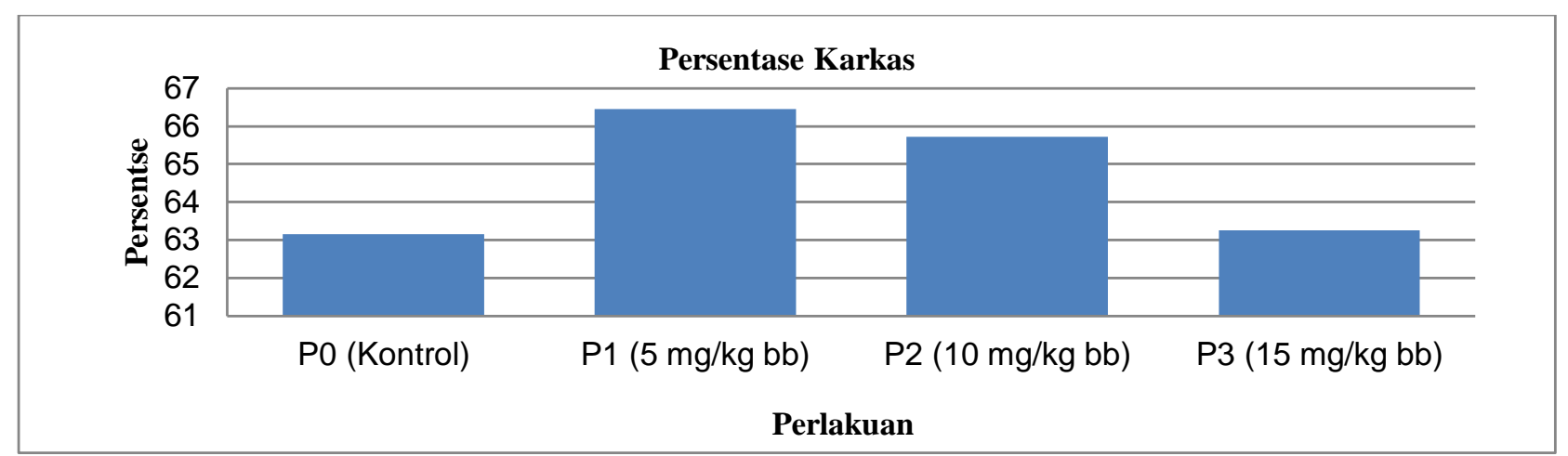

Gambar 1. Grafik rataan persentase karkas ayam broiler fase finisher.

Pengaruh terhadap panjang usus

Usus halus berkaitatan erat dengan pertumbuhan ayam broiler dikarenakan ditempat ini terjadi penyerapan sari-sari makanan dari ransum ketubuh ayam tersebut. Hal ini sesuai dengan pendapat Suprijatna et al. (2005) yang mengemukakan bahwa usus halus merupakan organ utama sebagai tempat pencernaan dan absorpsi pencernaan dikarenakan terdapat beberapa enzim didalam usus halus yang berfungsi mempermudah proses absorpsi serta mempercepat dan mengefisienkan pemecahan karbohidrat, protein ataupun lemak.

Penyerapan makanan pada usus halus ayam broiler terdapat pada lapisan dasar mukosa yaitu pada salah satu sel vili. Hal ini sesuai dengan pendapat Nuraini (2010) yang mengemukakan bahwa usus halus sebagai tempat pencernaan dan penyerapan zat-zat makanan yaitu pada lapisan mukosa yang diselaputi vili, sel vili tersebut adalah sel vili absorptif.

$$
\text { Suprijatna et al. }
$$
mengemukakan bahwa panjang usus halus bervariasi tergantung dengan kebiasaan makan unggas, panjang usus halus ayam dewasa mencapai $150 \mathrm{~cm}$, sedangkan menurut Blakely and Bade (1991) panjang usus besar mencapai 8-10 cm/ekor. Hal tersebut dapat disimpulkan bahwa panjang usus ayam dari pangkal usus sampai kloaka $158-160 \mathrm{~cm}$. Berikut kami sajikan data panjang usus ayam broiler fase finisher.

Penambahan ekstrak sarang semut (Myrmecodia sp) menggunakan media air minum secara statistik sidik ragam juga tidak berpengaruh nyata terhadap panjang usus ayam broiler $(\mathrm{P}>0,05)$, hal tersebut dapat dilihat pada Tabel 2. Pada tabel 2 menunjukkan hasil rataan tertinggi terdapat pada perlakuan 1 (P1) (5 mg/kg bb) disusul pada perlakuan $2(\mathrm{P} 2)(10 \mathrm{mg} / \mathrm{kg} \mathrm{bb})$ dan perlakuan 3 (P3) (15 mg/kg bb).

Rataan panjang usus tertinggi terdapat pada perlakuan 1 (P1). Hal ini disebabkan karena pemberian dosis pada perlakuan paling sedikit yaitu $5 \mathrm{mg} / \mathrm{kg}$ bb dan untuk rataan panjang usus terendah terdapat pada perlakuan $3(\mathrm{P} 3)(15 \mathrm{mg} / \mathrm{kg}$ bb) disebabkan pemberian dosis terlalu banyak. Pemberian dosis terlalu banyak kemungkinan besar menyebabkan radang usus pada ayam. Panjang usus pada perlakuan 3 (P3) walaupun mendapatkan hasil yang paling rendah yaitu mencapai rataan $169,8 \mathrm{~cm}$ dan dibawah kontrol (P0) yang mempunyai rataan $170,25 \mathrm{~cm}$ tetapi masih relatif lebih tinggi dari pendapat Brakely dan Bade (1991) serta Suprijatna et al. (2005) yang mengemukakan bahwa panjang usus ayam broiler dari pangkal usussampai kloaka mencapai $158-160 \mathrm{~cm}$. 
Tabel 2. Panjang Usus Ayam Broiler Fase Finisher.

\begin{tabular}{cccccccc}
\hline \multirow{2}{*}{ Perlakuan } & \multicolumn{5}{c}{ Ulangan } & Rata-rata & Notasi \\
\cline { 2 - 5 } & 1 & 2 & 3 & 4 & 5 & & \\
\hline P0 & 174,25 & 171,25 & 162 & 175,25 & 168,5 & 170,25 & Ns \\
P1 & 195,5 & 165,75 & 173 & 164,75 & 170 & 173,8 & Ns \\
P2 & 174,5 & 158,25 & 158,25 & 190 & 174,25 & 171,05 & Ns \\
P3 & 160,75 & 168,5 & 173,75 & 167,5 & 178,5 & 169,8 & Ns \\
\hline
\end{tabular}

Keterangan: Notasi ns (non significant) menunjukkan pengaruh tidak nyata $(\mathrm{P}>0,05)$.

Rataan panjang usus pada perlakuan 1 (P1) yang mendapatkan hasil tertinggi yaitu mencapai $173,8 \mathrm{~cm}$ dan diikuti bobot hidup ayam yang tinggi pula. Hal ini sesuai dengan pendapat Nuraini (2010) yang mengemukakan bahwa salah satu faktor yang memengaruhi panjang usus ayam yaitu ukuran tubuh ayam itu sendiri, di samping hal tersebut panjang usus kemungkinan besar juga dipengaruhi oleh serat kasar pada ransum. Hal ini sesuai dengan pendapat Syamsuhaidi (1997) yang menyatakan bahwa semakin tinggi serat kasar dalam ransum, maka penyerapan zat makanan dan laju pencernaan semakin lambat serta akan menyebabka usus semakin panjang, selain itu Amrullah (2004) juga menyatakan bila ransum mengandung tiga serat yang sulit dicerna seperti selulosa, lignin dan silika maka akan meningkatkan kinerja usus dalam mencerna dan menyerap zat makanan yang ditunjukkan semakin panjangnya usus. Grafik panjang usus untuk lebih jelasnya kami tampilkan pada Gambar 2.

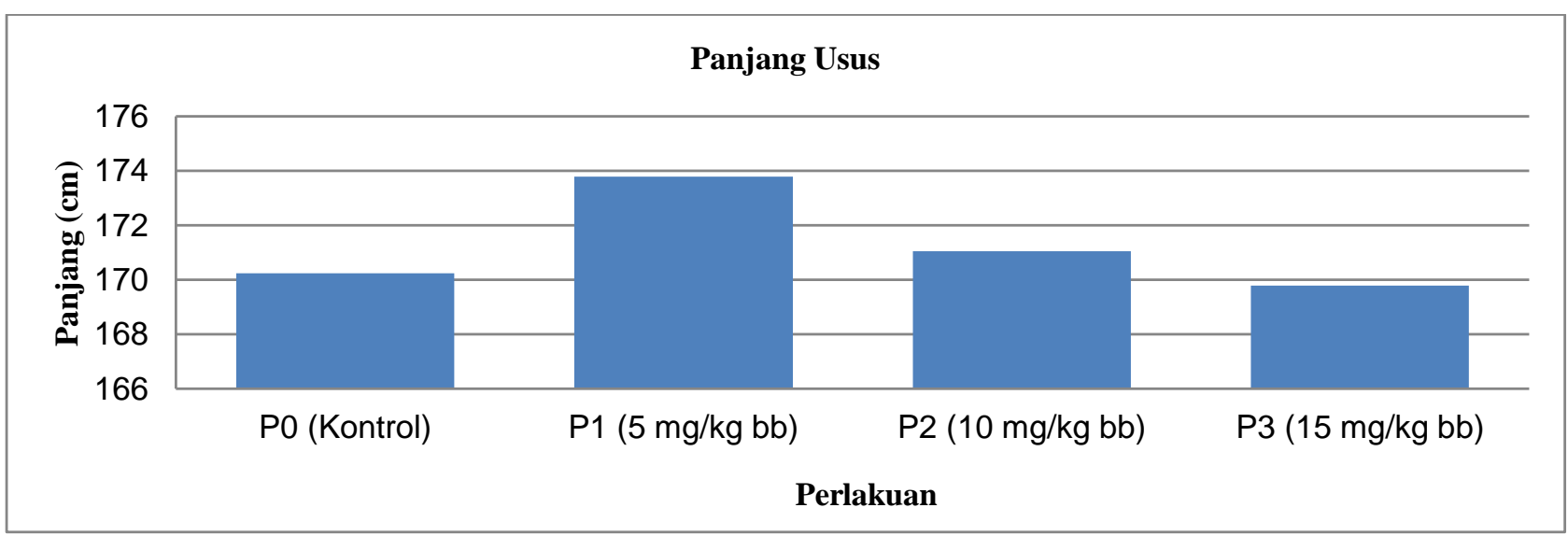

Gambar 2. Grafik rataan panjang usus Ayam broiler fase finisher

\section{KESIMPULAN}

Pemberian perlakuan terhadap persentase karkas menunjukkan hasil yang lebih tinggi dibandingkan dengan kontrol, sedangkan pemberian perlakuan terhadap panjang usus ada salah satu yang menunjukkan hasil lebih rendah dibandingkan dengan kontrol. Penambahan ekstrak sarang semut (Myrmecodia $s p$ ) tidak memberikan pengaruh nyata terhadap persentase karkas dan panjang usus ayam broiler.

\section{DAFTAR PUSTAKA}

Amrullah, I. K. (2004). Manajemen ternak ayam broiler. Bogor: IPB-Press.

Amrullah, I. K. (2004). Nutrisi ayam broiler. Bogor: Lembaga Satu Gunung Budi.

Blakely, D., \& Bade, D. H. (1991). Ilmu peternakan. Penerjemah: Bambang Srigandono (4th ed.). Yogyakarta: Gadjah Mada University Press. 
Dewi, H. R. (2007). Evaluasi beberapa ransum komersial terhadap persentase bobot karkas, lemak abdominal dan organ dalam ayam broiler. Skripsi. IPB Bogor.

Ernawati., \& Susanti, H. (n.d.). Penghambatan aktivitas xanthine oxidase oleh ekstrak etanol sarang semut(myrmecodia tuberosa) secara in vitro. Universitas Ahmad Dahlan Yogyakarta.

Lisnanti, E., \& Fitriyah, N. (2017). Efektivitas pemberian ekstrak sarang semut (myrmecodia .sp) terhadap respon antibody avian influenza subtipe H5n1. TERNAK TROPIKA Journal of Tropical Animal Production, 18(2), 52-58. https://doi.org/10.21776/ub.jtapro.20 17.018.02.8

Mubarok, A., \& Sri, S. (2016). Persentase karkas dan lemak abdomen ayam broiler yang diberi perlakuan berbeda pada frekuensi pemberian pakan dan dosis penambahan dedak fermentasi. Jurnal Fillia Cendekia, 1(1), 1-9.

Nuraini. (2010). Performa, persentase karkas, lemak abdominal dan organ dalam ayam broiler dengan penambahan prebiotik dari tongkol jagung. IPB Bogor.

Saleha, A., Myaing, T., Ganapathy, K., Zulkifli, I., Raha, R., \& Arifah, K. (2009). Possible effect of antibiotiksuplemented feed and enviroment on the occurrence of multiple antibiotik resistant escherichia coli in chikens. International Journal of Poultry Science, 8(1), 28-31
Sibarani, J., Yunianto, V. D., \& Mahfudz, L. D. (2016). Persentase Karkas dan Non Karkas Serta Lemak Abdominal Ayam Broiler Yang Diberi Acidifier Asam Sitrat Dalam Pakan Double Step Down. Animal Agriculture Journal, 3(2), 273-280.

Simanjuntak, F., \& A, S. M. (2010). Isolasi senyawa aktif dari ekstrak hipokotil sarang semut (myrmecodia pendens merr. \& perry) sebagai penghambat xantin oksidase. Jurnal Ilmu Kefarmasian Indonesia, 8(1), 49-54.

Singarimbun, J. F., Mahfuds, L. D., \& Suprijatna, E. (2013). Pengaruh pemberian pakan dengan level protein berbeda terhadap kualitas karkas hasil persilangan ayam bangkok dan ayam arab. Animal Agriculture Journal, 2(2), 15-25.

Soeparno. (2005). Ilmu dan teknologi daging (4th ed.). Yogyakarta: Gadjah Mada University Press.

Subroto, A., \& Saputro, H. (2008). Gempur penyakit dengan sarang semut. Jakarta: PT. Gramedia Pustaka Utama.

Suprijatna, E.U., \& Atmomarsono, R. K. (2005). Ilmu dasar ternak unggas. Jakarta: Penebar Swadaya.

Syamsuhaidi. (1997). Penggunaan duckweed (Family Lemnacea) sebagai pakan serat sumber protein dalam ransum ayam pedaging. IPB Bogor.

Syukron, M. (2006). Kandungan lemak dan kolesterol daging serta persentase organ dalam ayam broiler yang diberi ransum finisher dengan penambahan kepala udang. IPB Bogor. 
Van Den Bogaard, A. E., Willems, R., London, N., Top, J., \& Stobberingh, E. E. (2002). Antibiotic resistance of faecal enterococci in poultry, poultry farmers and poultry slaughterers. The Journal of Antimicrobial Chemotherapy, 49(3), 497-505. 